\title{
Wybrane czynniki wpływające na mikrobiom układu pokarmowego przeżuwaczy i jego skład bazowy
}

\author{
dr inż. Paulina Cholewińska ${ }^{\circledR}$ \\ mgr Natalia Szeligowska, \\ inż. Jakub Smoliński, \\ inż. Marcel Bawej
}

Instytut Hodowli Zwierząt, Uniwersytet Przyrodniczy we Wrocławiu

https://doi.org/10.18388/pb.2021_374

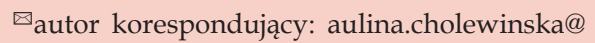
upwr.edu.pl

Słowa kluczowe: mikrobiom, przeżuwacze, układ pokarmowy, czynniki środowiskowe, czynniki genetyczne

Wykaz skrótów: HG - dieta przeżuwaczy oparta o wysoką zawartość ziaren (ang. HighGrain); LKT - lotne kwasy tłuszczowe; LPS - lipopolisacharydy; SARA - subkliniczna kwasica żwacza (ang. Sub-Acute Ruminal Acidosis)

\section{STRESZCZENIE}

M ikrobiom układu pokarmowego przeżuwaczy należy do jednych z bardziej skomplikowanych przykładów współdziałania mikroorganizmów i gospodarza. Mikrobiom układu pokarmowego przeżuwaczy niezbędny jest do pozyskiwania energii z pożywienia roślinnego, co nie byłoby możliwe bez jego udziału. Na mikrobiom układu pokarmowego składają się bakterie, archeony, pierwotniaki oraz grzyby. Najbardziej liczną grupą są bakterie, gdzie główne gromady to Firmicutes i Bacteroidetes. Skład mikrobiomu pod względem ilościowym jak i jakościowym zależny jest od czynników tj. dieta, wiek, stan zdrowia, środowisko. Dodatkowo mogą na niego wpływać czynniki genetyczne czy biologiczne (np. płeć). Mikroorganizmy bytujące w układzie pokarmowym przeżuwaczy w znaczącym stopniu wpływają na ich stan zdrowia czy wskaźniki produkcyjne, co z kolei związane jest nie tylko z prawidłowym przyswajaniem substancji odżywczych z pokarmu, ale również z funkcją mikrobiomu jako swoistego układu immunologicznego.

\section{WPROWADZENIE}

Szacuje się, że przy zastosowaniu zrównoważonych praktyk rolniczych utrzymuje się obecnie ok. 3,9 miliarda przeżuwaczy. Pozwala to między innymi na wykorzystanie przemysłowych produktów ubocznych jako źródła pożywienia, niezagospodarowanych użytków poprzez wypas, a także pozyskiwanie energii z niskiej jakości paszy. W ten sposób można uzyskać wysoką jakość wyrobów, takich jak mleko i mięso. Dodatkowo szacuje się, że w 2050 roku liczba przeżuwaczy zwiększy się do 9,2 miliona. Związane jest to z bogaceniem się społeczeństwa oraz ze zwiększeniem liczby ludności i zapotrzebowania na produkty pochodzenia zwierzęcego [1,2].

Przeżuwacze charakteryzują się wysokim poziomem złożoności układu pokarmowego oraz składu mikrobiomu, czyli genomów tworzących mikrobiotę. Mikrobiom ich układu trawiennego jest jednym z bardziej skomplikowanych przykładów współdziałania mikroorganizmów i zwierzęcia. Podstawową funkcją mikroorganizmów zasiedlających żołądki zwierząt przeżuwających jest rozkład cząstek roślinnych i przetworzenie ich na energię dla zwierzęcia. Z procesu fermentacji mikrobiologicznej powstają lotne kwasy tłuszczowe (LKT), które stanowią około 70\% zapotrzebowania na energię i mają bezpośredni wpływ na parametry fizjologiczne (takie jak: rozwój, stan zdrowia, wskaźniki produkcyjne), a także na jakość produktów pochodzenia zwierzęcego [3-5].

Mikrobiom układu pokarmowego składa się z bakterii, archeonów, grzybów i pierwotniaków. Przeważającą grupą są bakterie, które stanowią $10^{9}-10^{10} / \mathrm{ml}$ treści żwacza. Należą do nich gromady Firmicutes oraz Bacteroidetes, będące głównie bakteriami beztlenowymi lub względnie tlenowymi [4]. Najliczniej zasiedlone są przedżołądki, następnie jelito grube, przy czym ilość mikroorganizmów zwiększa się w kierunku doogonowym. Bakterie występujące w żwaczu stanowią około 90\% jego biomasy, po czym ich ilość znacząco spada w jelicie cienkim. W jelicie grubym natomiast występuje znaczący wzrost populacji drobnoustrojów do poziomu podobnego w żwaczu [2,6].

\section{SKLAD PODSTAWOWY MIKROBIOMU UKŁADU POKARMOWEGO PRZEŻUWACZY}

\section{BAKTERIE}

Jak już wcześniej wspomniano, bakterie stanowią najbardziej liczna grupę mikroorganizmów układu pokarmowego zwierząt przeżuwających. Skład ilościowy i jakościowy zależny jest od czynników takich jak dieta, środowisko, stan zdrowia, rasa, czynników osobniczych, a także biologicznych np. płeć $[2,7,8]$. Główną rolą bakterii w układzie pokarmowym przeżuwacza jest rozkład celulo- 
zy i hemiceluloz, jednakże biorą one również udział w rozkładzie innych składników pokarmowych jak tłuszcze oraz białka $[9,10]$.

Gromadami najliczniej zasiedlającymi układ pokarmowy wszystkich przeżuwaczy, są Firmicutes i Bacteroidetes. Rzadziej natomiast obserwowane są Proteobacteria oraz Fibrobacter. Tenericutes i Actinobacteria występują w niewielkiej ilości, co związane z dietą zwierząt, czyli pokarmem roślinnym. Najbardziej liczne gromady bakteryjne związane są przede wszystkim z rozkładem pokarmu o dużej ilości włókna surowego oraz polisacharydów [3,5,11,12].

Gromada Firmicutes należy do Gram-dodatnich bakterii, obejmujących rodzaj Clostridium oraz Bacilli. Bakterie z rodzaju Clostridium tj. C. sticklandii, Selenomonas ruminantum, Eubacterium ruminantum, powodują głównie degradację białek. Jednakże, do tego rodzaju należą również mikroorgani- zmy, rozkładające celulozę i hemicelulozę tj. Butyvibriofibro solvens, Ruminococcus flavensis, a także tłuszcze - Anaerovibrio lipolityca czy kwasy tłuszczowe np. Megasphaera elsdenii [13-16]. Bakterie z rodzaju Clostridium odpowiadają również za produkcję metanu w żwaczu. Ze względu na to, że degradują białka, produkują one dwutlenek węgla, wodór, kwasy organiczne oraz etanol. Są to substraty wykorzystywane w procesie metanogenezy, których produktem końcowym jest metan $\left(\mathrm{CH}_{4}\right)$. Drobnoustroje te charakteryzują się również tworzeniem przetrwalników oraz są obligatoryjnymi beztlenowcami [14-18]. Rodzaj Bacilli natomiast skupia bakterie, które do wzrostu potrzebują egzogennych peptydów i aminokwasów powstałych z proteolizy białek. Nie wytwarzają one przetrwalników, a także w tej grupie występują mikroorganizmy warunkowo tlenowe, takie jak rodzina Lactobacillaceae. Odpowiada m.in. za rozkład białek takich jak albuminy, globuliny czy kazeiny. Występują one licznie nie tylko $\mathrm{w}$ układzie pokarmowym, ale i w

Tabela 1. Mikrobom układu pokarmowego przeżuwaczy występujące w układzie pokarmowym przeżuwaczy (na podstawie: 15,28-32).

\section{Firmicutes}

- Bakterie Gram dodatnie - głównie rodzaje Clostridia i Bacilli,

- Najbardziej liczna grupa bakterii.

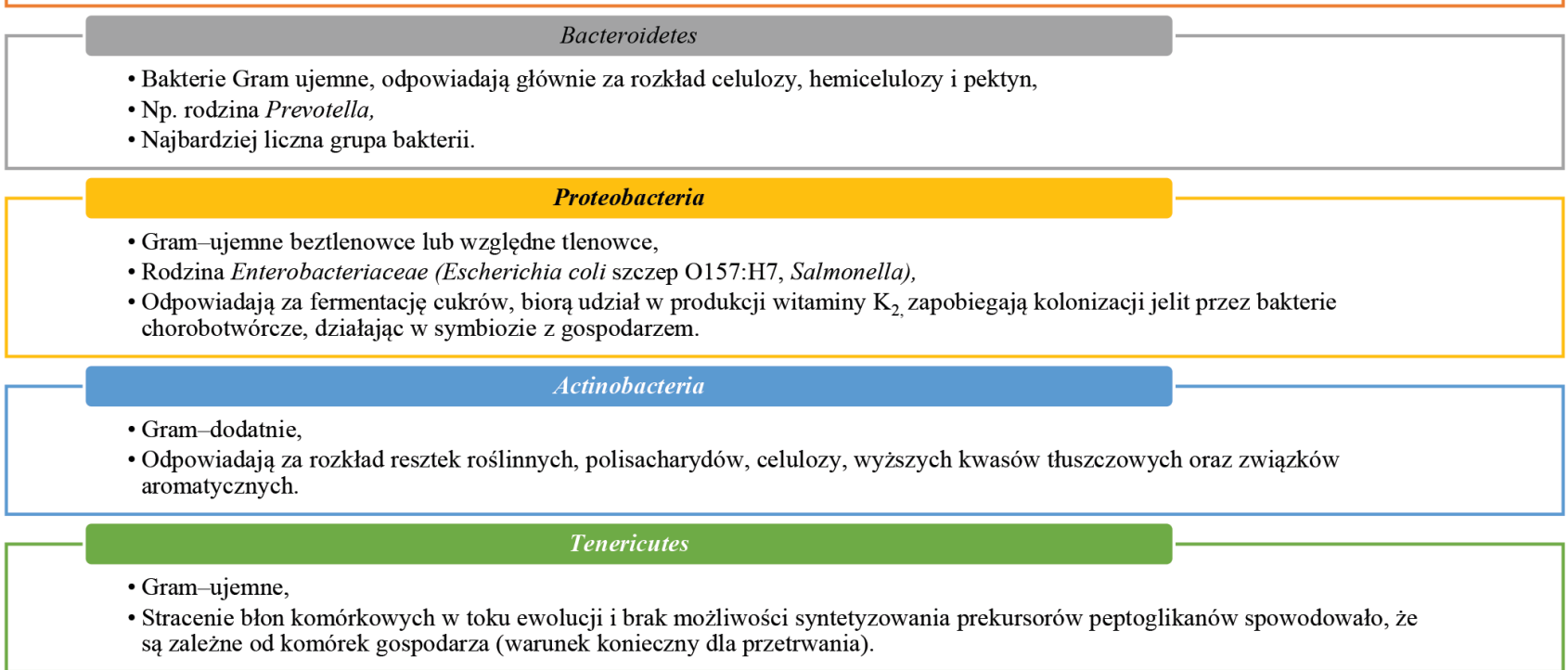

\section{Fibrobacter}

- Fibrobacter succinogenes,

- Odpowiada za rozkład celulozy, a produktami tego procesu są estry kwasów: mrówkowego, octowego i bursztynowego.

- Organizmy występujące rzadziej, odpowiadające za produkcję metanu,
- Methanobacterium ruminantum,
- Methanobrevibacter sp.,
- Methanosarcina barkeri.

\section{Fungi}

- Grzyby należące do gromady Neocallimastigo-mycota tj. Anaeromyces, Caceomyces, Cyllamyces,

- Odpowiadają za początkowy rozkład pokarmu roślinnego.

Protozoa
• Rodzina Isotrichia, Dasytrichia, Entodinium, Diplodinium i Endiplodinium,
• Odpowiadają za dostarczenie gospodarzowi pełnowartościowego białka.


mleku i jego przetworach. Dodatkowo charakteryzują się działaniem probiotycznym, wytwarzając bakteriocyny (np. Streptococcus thermophilus, Enterococcus faecium). Substancje te działają antagonistycznie na część drobnoustrojów patogennych takich jak: Escherichia coli, Salmonella typhimurium, Staphylococcus aureus, Clostridium perfringens, Listeria sp., Klebsiella sp., Proteus sp. Lactobacillaceae wytwarzają również metabolity jak kwas mlekowy, octowy, nadtlenek wodoru. Substancje te działają bakteriobójczo lub bakteriostatycznie na patogenne mikroorganizmy [15,19-22].

Kolejna najbardziej liczna gromada bakteryjna w układzie pokarmowym przeżuwaczy, czyli Bacteroidetes, należy do Gram-ujemnych bakterii (ściana komórkowa nie tworzy wielowarstwowej błony). Drobnoustroje te odpowiadają głównie za rozkład hemicelulozy i pektyn. Do tej gromady należy szczep P. Brytanii 25A, który podobnie jak bakterie kwasu mlekowego, charakteryzuje się działaniem probiotycznym. Polega ono na wytwarzaniu metabolitów niekorzystnie działających na gatunki patogenne i adhezji do błon śluzowych układu pokarmowego, determinując zasiedlenie mikroorganizmów. Skuteczność działania probiotycznego opiera się na konkurencyjnym wykorzystywaniu substancji odżywczych przez drobnoustroje [23-25]. Dodatkowo mikroorganizmy z rodzaju Prevotella często nie wytwarzają enzymów trawiących celulozę, dlatego jest dla nich istotne współdziałanie z bakteriami celulolitycznymi [26,27].

Inne gromady zasiedlające układ pokarmowy przeżuwaczy to Actinobacteria, Tenericutes, Proteobacteria i Fibrobacter. Najmniej liczne, stanowiące wspólnie około 3\% całej populacji to Actinobacteria i Tenericutes (Tab. 1) [15,28,29].

\section{ARCHEONY I EUKARIONTY}

Archeony różnią się od wcześniej opisanych bakterii budową. Charakteryzują się brakiem w cytoplazmie mitochondriów, lizosomów, retikulum endoplazmatycznego, aparatu Golgiego oraz błony jądrowej. Posiadają natomist charakterystyczne dla siebie struktury takie jak archaella, pile, haczyki czy kaniule. Archeony występujące w układzie pokarmowym to obligatoryjne beztlenowce oraz są głównie metanogenne. Organizmy zasiedlają go, już w 30 godzin po porodzie [33-35]. Stanowią od 3 do $4 \%$ populacji mikroorganizmów w układzie pokarmowym i obejmują gatunki takie jak Methanobacterium ruminantum, Methanobrevibacter sp., Methanosarcina barkeri. Ilość i różnorodność archeonów może być związana z dietą, środowiskiem, stanem zdrowia i genotypem zwierząt $[36,37]$. Wykorzystują dwutlenek węgla oraz wodór jako substraty w procesie metanogenezy. Zapobiega on nadmiernej produkcji etanolu i kwasów organicznych powstających podczas fermentacji żwaczowej. Dodatkowo wpływa on na obniżenie ciśnienia i ułatwia rozkład włókna przez przekształcanie wodoru w metan. Wadami tego procesu jest znaczny spadek pozyskiwania energii z pożywienia, która może sięgać nawet do $12 \%$ dla gospodarza, ze względu na wykorzystanie kwasów organicznych niezbędnych do produkcji LKT przez mikroorganizmy tj. kwas mrówkowy i octowy [36,38,39]. Archeony konkurują również z bakteriami metanogennymi np. Clostridia w pozyskiwaniu wodoru cząsteczkowego niezbędnego do metanogenezy $[4,33,36,40]$. Natomiast współdziałają z or- ganizmami wytwarzającymi wodór i kwasy organiczne, takimi jak bakterie, pierwotniaki i grzyby $[33,40]$.

Spekuluje się, że część archeonów jest powiązana z pierwotniakami występującymi w żwaczu. W niektórych pracach jak np. Jassen i Kris [37] podejrzewano, że eliminacja pierwotniaków ze żwacza była jednym z czynników zmieniających skład populacji archeonów zarówno pod względem ilościowym, jak i jakościowym. Pierwotniaki w układzie pokarmowym przeżuwaczy to głównie organizmy beztlenowe, głównie endosymbiotyczne. W $1 \mathrm{ml}$ żwacza występuje ich około $10^{4}-10^{6}$, jednakże ich ilościowa, jak i jakościowa struktura silnie związana jest z gatunkiem zwierzęcia oraz dietą. Zbyt gwałtowne, a także długotrwałe obniżenie poziomu pH może wpłynąć na spadek liczebności Protozoa w płynie żwaczowym, a nawet do długotrwałej ich eliminacji. Głównymi funkcjami tych jednokomórkowych organizmów, są fermentacja paszy roślinnej, rozkład bakterii kolonizujących żwacz, metabolizm nadmiaru tlenu. Dodatkowo są odpowiedzialne za przyswajanie aminokwasów wytworzonych przez mikroorganizmy, a strawione w dalszej części układu pokarmowego dostarczają gospodarzowi pełnowartościowego białka. Pierwotniaki zasiedlające przedżołądki przede wszystkim należą do rodziny Izotrichia, Dasytrichia, Entodidium, Diplodinium i Endiplodinium. Mimo małej liczebności, ze względu na swój rozmiar stanowią one połowę ich biomasy [15,41,42].

Nastepną grupą eukariontów wystepującą w układzie pokarmowym przeżuwaczy są grzyby, należące do rodziny Neocallimastigomycota takie jak Anaeromyces, Caceomyces, Cyllamyces. Ich główną funkcją jest degradacja zdrewniałych cząstek roślinnych, która polega na kolonizacji roślin przez grzyby, po czym dochodzi do wydalania enzymów zewnątrzkomórkowych (celulolitycznych, hemicelulolitycznych, glikolitycznych i proteolitycznych). Ich wydzielanie powoduje rozkład struktury roślinnej, dzięki czemu zwiększa się ilość miejsca dla nich. Co więcej, biokatalizatory wytwarzane przez grzyby umożliwiają trawienie prawie wszystkich polimerów roślinnych. Działają one również w symbiozie z innymi mikroorganizmami w żwaczu jak np. bakterie metanogenne. $W$ trakcie degradacji dochodzi do wytwarzania $\mathrm{CO}_{2}, \mathrm{H}_{2}$, etanolu i kwasów organicznych niezbędnych w procesie metanogenezy [15].

\section{WYBRANE CZYNNIKI WPŁYWAJĄCE NA MIKROBIOM UKŁADU POKARMOWEGO PRZEŻUWACZY}

Podsumowanie czynników wspływających na mikrobiom przeżuwaczy przedstawia rycina 1 .

\section{ŚRODOWISKO I ROZWÓJ}

Elastyczność, którą charakteryzują się przeżuwacze w odniesieniu do pokarmu jaki spożywają, pozwoliła im na zasiedlenie wielu różnych siedlisk, obejmujących szeroki zakres klimatyczny. Różnice w społecznościach mikroorganizmów w układzie trawiennym związane są z konwersją paszy oraz metanogenezą. Pasze podawane przeżuwaczom w odmiennych miejscach geograficznych różnią się, nie tylko składem botanicznym, ale i chemicznym, czego dowiódł w swoich badaniach Henderson i in. [8]. 


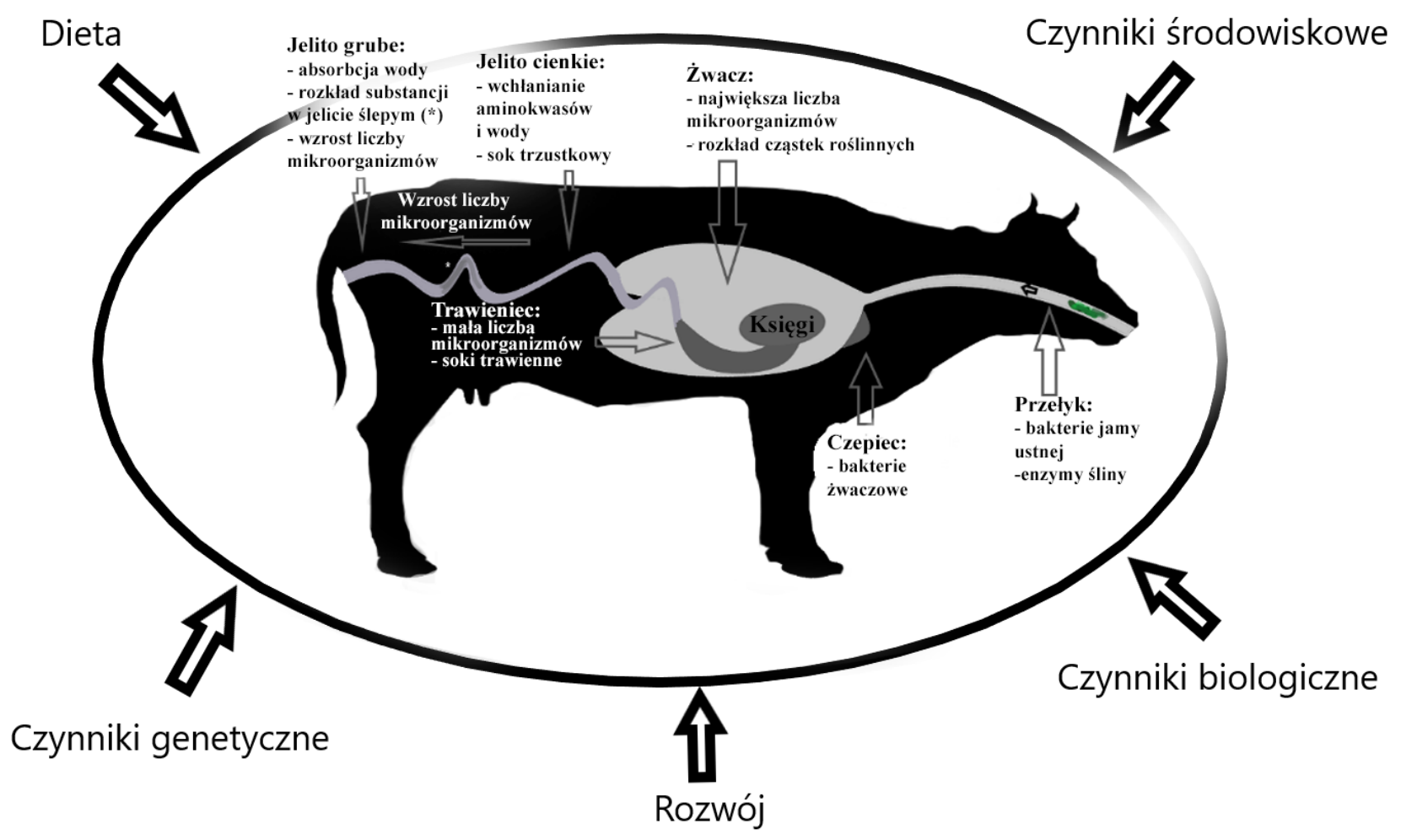

Rycina 1. Podsumowanie czynników wspływających na mikrobiom przeżuwaczy.

Mikrobiom układu pokarmowego przeżuwaczy rozwija się $\mathrm{w}$ okresie postprenatalnym. $\mathrm{W}$ tym czasie dochodzi do jego zasiedlenia (wody płodowe, kał matki, środowisko zewnętrzne). W pierwszych tygodniach życia kosmki jelitowe nie są wykształcone oraz nie funkcjonuje żwacz, jednak mikroorganizmy związane z późniejszą fermentacją żwaczową są obecne, choć w zmniejszonej ilości. U młodych przeżuwaczy intensywna fermentacja i znaczący wzrost poziomu mikroflory układu pokarmowego zaczyna się wraz z przyjmowaniem stałego pożywienia. Prawidłowy rozwój układu trawiennego, $\mathrm{w}$ tym okresie jest fizjologicznym wyzwaniem dla zwierzęcia. Jego dojrzewanie obejmuje trzy etapy, gdzie odpowiednio każdy warunkuje m.in. homeostazę organizmu [19,44-46]. Badania przeprowadzone przez Tamate i in. [47] wykazały, że w czasie rozwoju żwacza wysoce istotne jest żywienie przeżuwaczy. Przedłużony brak dostępu do paszy stałej spowalnia rozwój żwacza do 12 tygodnia życia. Spożycie paszy stałej/sypkiej umożliwia rozwój mikroflory, ponieważ wpływa ona na produkcję LKT inicjujących rozwój kosmków jelitowych [44].

Na wczesnym etapie życia przeżuwacza możliwe jest odpowiednie manipulowanie mikroflorą $\mathrm{w}$ taki sposób, aby $\mathrm{w}$ przyszłości była ona stabilniejsza i odpowiednio zróżnicowana. Badania wykonane na koźlętach, mające na celu wprowadzenie zmian mikrobiomu, za pomocą interwencji żywieniowej, wykazało, że zastosowane modyfikacje spowodowały zmniejszenie emisji metanu o 59\%, w porównaniu do grupy kontrolnej. Zastosowanie odpowiednio dopasowanych dawek pokarmowych oraz profilak- tyczne podawanie probiotyków i prebiotyków może w późniejszym czasie u młodych osobników odpowiednio wzmocnić barierę immunologiczną. Dodatkowo również ustabilizować stan fizjologiczny zwierzęcia, a co za tym idzie poprawić jego wskaźniki produkcyjne i wpływ na środowisko. Natomiast badania przeprowadzone w ostatnim czasie wykazały, że mikroflora dorosłych osobników jest już na tyle stabilna, że możliwości manipulacji są znikome i krótkotrwałe w porównaniu do młodych osobników. Jednakże prócz czynnika żywieniowego, istotny jest system utrzymania zwierząt $[45,46,48]$. W badaniach Fonty i in. [49] wykazano wpływ systemu odchowu na skład mikroflory i rozwój u jagniąt. U młodych osobników utrzymywanych w kojcach indywidualnych dochodziło do wolniejszego rozwoju i wzrostu liczby bakterii celulolitycznych, $\mathrm{w}$ porównaniu do grupy utrzymywanej $\mathrm{w}$ kojcach grupowych, co skutkowało także mniejszymi przyrostami.

Dodatkowo w badaniach Deng i in. [50] na przykładzie bydła mięsnego, wykazano, że zmiany $\mathrm{w}$ środowisku związane $\mathrm{z}$ transportem młodych osobników mają znaczący wpływ na stosunki między poziomami różnych grup mikroorganizmów. W czasie 6 h po transporcie doszło do wzrostu ilości bakterii Fibrobacter succinogenes, Ruminoccocus flavefaciens, Ruminococcus amylophylus oraz Prevotella albensis, natomiast nastąpił spadek ilości Prevotella brytanii, P. ruminicola, Anaerovibrio lipolyitica, Succinivibrio dextrinosolvens do 3 dnia po transporcie. $W$ tym okresie doszło także do spadku pH żwacza oraz zmniejszenia produkcji kwasu propionowego i masłowego, oraz wzrostu produkcji kwasu octowego. Dopiero po 15 dniach nastąpiła stabilizacja procesów oraz poziomu bakterii w przedżołądku. Tak długotr- 
wałe obniżenie $\mathrm{pH}$ ma szczególnie niekorzystny wpływ na poziom pierwotniaków w żwaczu (redukcja) co może prowadzić do mniejszego wykorzystania białka paszowego. Pierwotniaki są głównym źródłem pełnowartościowego białka dla przeżuwaczy, przez co ich zmniejszona ilość może wpłynąć negatywnie na przyrosty w okresie adaptacji mikroflory, po zmianie środowiska $[41,51]$.

Inne czynniki środowiskowe wywołujące stres, takie jak odstawienie od matki, transport, ubój itp. mają znaczący wpływ na mikrobiom układu pokarmowego. Jest on jego naturalną barierą ochronną oraz odgrywa istotną rolę $\mathrm{w}$ rozwoju wrodzonych i adaptacyjnych odpowiedzi immunologicznych, dzięki pośrednictwu szeregu metabolitów pochodzących od mikroorganizmów [52]. Przeprowadzone badania w ostatnim czasie dowodzą, że istnieje dwukierunkowa komunikacja pomiędzy mikroflorą układu pokarmowego a ośrodkowym układem nerwowym. Zaburzenia pod wpływem stresorów psychologicznych wywołują odpowiedź neuroendokrynną, co może oddziaływać bezpośrednio lub pośrednio na mikrobiom. W takim przypadku prowadzi to, do zwiększenia wzrostu markerów zapalnych przy braku jawnej infekcji. Dochodzi w tym czasie często do spadku poziomu bakterii z rodziny Lactobacillaceae i innych warunkowych tlenowców. Powoduje to zwiększenie ryzyka wystąpienia chorób wywoływanych przez drobnoustroje patogenne [53]. Przedłużający się stres psychologiczny może skutkować spadkiem poziomu produkcji mucyny, co z kolei związane jest ze wzrostem ilości kwaśnych mukopolisacharydów na powierzchni śluzówki - ułatwia to kolonizację jelit przez organizmy patogenne [7,54,55].

\section{DIETA}

W dzisiejszych czasach dieta bydła oparta jest głównie o pasze wysokoenergetyczne i wysokobiałkowe z niską zawartością włókna. Dodatkowo częstym błędem, w trakcie utrzymywania zwierząt jest nieodpowiednie dopasowanie diety, w związku ze zmianami stanu fizjologicznego. Występuje on w okresie między końcem laktacji a zasuszeniem. Podczas szybkich modyfikacji w dawkach pokarmowych mikroorganizmy mają ograniczone możliwości adaptacji, co przekłada się na zmiany w składzie mikrobiomu (często na korzyść patogenów) [2,10,56]. Badania płynu żwacza z różnych środowisk wykazały, że liczebność bakterii z gromady Bacteroidetes zwiększa się u bydła utrzymywanego na pastwisku. Natomiast, w przypadku diety bazującej na paszy treściwej dochodzi do wzrostu liczebności rodzaju Prevotellaceae i należącej do typu Proteobacteria rodziny Succinivibrionaceae, niezależnie od gatunku przeżuwaczy. Zmiany w rodzaju pokarmu u przeżuwaczy wpływają również na dostępność substancji odżywczych. W badaniach wykazano, że poszczególne bakterie i ich metabolizm w układzie pokarmowym mogą powodować różnice w wydajności pobieranych przez zwierzę pasz w diecie o niskiej zawartości energii oraz zmianie, jakiej ulega po wprowadzeniu diety wysokoenergetycznej $[2,10,57,58]$. Dodatkowo częste stosowanie pasz treściwych zbyt sypkich skutkuje zmniejszeniem trawienia celulozy. Powoduje to zbyt szybki jej rozkład, a także innego polisacharydu, jakim jest skrobia. Tego typu proces wpływa, na znaczne i długotrwałe obniżenie pH żwacza do 5.5, skutkując spowolnieniem syntezy LKT przez mikroflorę. Dochodzi do osłabienia procesu trawienia i przyspieszenia przepływu treści pokarmowej przez układ. W efekcie końcowym powoduje to obniżenie poziomu tłuszczu w mleku [23,59].

Przeżuwacze będące na diecie opartej o wysoką zawartość ziaren (HG), szczególnie kukurydzy, charakteryzowały się mikroflorą o dużym udziale bakterii Firmicutes wraz z niską liczebnością Bacteroidetes. Zwiększyła się również liczba pierwotniaków oraz archeonów. Skutkowało to zwiększeniem poziomu kilku toksycznych i zapalnych związków, w tym endotoksyn, tryptamin, tyramin, histamin i fenylooctanu. Przeprowadzone w ostatnich czasach badania sugerują, że istnieją pewne potencjalne zależności między metabolitami w żwaczu i niektórymi gatunkami drobnoustrojów. Odnieść je można, do stosowanych interwencji żywieniowych w celu zmniejszenia ryzyka występowania kwasicy żwacza, spowodowanych mikrobiologicznymi zmianami składu [60]. Modyfikacje w populacji drobnoustrojów, a co za tym idzie, związane $\mathrm{z}$ nimi odpowiedzi immunologiczne organizmu, które są prawdopodobnie związane $\mathrm{z}$ etiologią kwasicy, wraz z wystąpieniem kwasicy dochodzi do podniesienia poziomu liposacharydów (LPS) w żwaczu. Badania Khafipour i in. [11] wykazały, że przy wzroście LPS w żwaczu następował wzrost bakterii Gram-ujemnych tj. Bacteroidetes, Prevotella ruminicola. Jednakże w zależności od stosowanej paszy zaobserwowano dodatkowe skutki. Przy spożywaniu ziaren zbóż, LPS pojawiał się we krwi oraz zwiększało się ryzyko stanów zapalnych. Natomiast przy podawaniu granulatu z lucerny, nie dochodziło do przeniknięcia LPS do układu krwionośnego. Wykazano, iż typ zastosowanej paszy wysokobiałkowej ma znaczący wpływ na wystąpienie SARA.

Zmniejszenie różnorodności mikroorganizmów wiąże się z zaburzeniami metabolicznymi, tj. podostrą i ostrą kwasicą, ale również zwiększeniem się ryzyka infekcji pozajelitowych i obniżeniem odporności organizmu [56,61, 62]. Biorąc pod uwagę, że mikroflora pełni także funkcje swoistego układu immunologicznego, nieprawidłowości w jego składzie mogą negatywnie wpłynąć na stan zdrowia, nie tylko w związku z chorobami układu pokarmowego, ale i ogólnoustrojowe. Jako aktywny immunologicznie organ jest on nieustannie stymulowany przez bodźce pochodzenia zarówno zewnętrznego (mikroorganizmy dostające się wraz z pokarmem), jak i wewnętrznego (warunkowo chorobotwórcze mikroorganizmy) [2].

Odpowiedni skład oraz ilość mikrobiomu wpływa na prawidłowy rozwój naczyń włosowatych w jelitach, które warunkują wchłanianie substancji odżywczych. Zmniejszenie się ilości lub zmiana w składzie mikroorganizmów może powodować obniżenie odporności gospodarza. Zwiększa to ryzyko wystąpienia stanów zapalnych, infekcji jelitowych oraz pozajelitowych np. mastitis. W takich przypadkach możliwe jest namnażanie się warunkowo chorobotwórczych mikroorganizmów, tj. E. coli, prowadzących do zatrucia pokarmowego. Zbyt duża ilość drobnoustrojów patogennych (np. Salmonella, Clostridium) wiąże się z powstawaniem endotoksyn, powodujących ogólne zatrucie organizmu, a nasilona i przewlekła endotoksemia skutkuje 
stanem zapalnym i uszkodzeniem tkanki gruczołowej narządów wewnętrznych, w tym trzustki $[10,63]$.

\section{CZYNNIKI BIOLOGICZNE I GENETYCZNE.}

Przeżuwacze różnią się między sobą, podobnie, jak i ludzie, pod względem biologicznym (np. płeć) jak i genetycznym, co z kolei może być uznawane za czynniki determinujące skład mikrobiologiczny w układzie pokarmowym $[2,62]$. Każdy osobnik również charakteryzuje się własnym, osobniczym mikrobiomem, co coraz częściej jest uważane za fenotypową cechę zwierzęcia $[8,64]$.

Badania przeprowadzone przez Turnbaugh i in. [65] na mikrobiomie ludzkim wykazały, że jest on wspólny częściowo dla członków rodzin, jednakże istnieją różnice osobnicze. Otrzymane wyniki sugerują, że taka mikroflora występuje tylko w przypadku małej populacji. Co więcej, badania Qin $\mathrm{i}$ in. [66], umożliwiły wytypowanie na poziomie gatunku wspólnych mikroorganizmów w populacji kontynentu (Europy). Badanie to przeprowadzone na 124 Europejczykach wykazało, że 18 gatunków bakterii wystąpiło we wszystkich badanych próbach, a 57 u 90\% osób z tej samej populacji, obejmującej region Europy. Podobne zależności zostały również wykazane w przypadku przeżuwaczy $[5,67]$. $W$ realizowanych przez wymienionych autorów badaniach wykazane zostało, że głównymi gromadami zasiedlającymi układ pokarmowy są gromady Firmicutes i Bacteroidetes. Ich populacja stanowi średnio 50\% ogólnej liczby bakterii. Jednakże w doświadczeniu Lopes i in. [67] wykazano także różnice osobnicze. Badane owce różniły się poziomem gromady Firmicutes względem Bacteroidetes. Wnioski podobne do pracy Li i in. [68] sugeruje także Mamun i in. [69], którzy udokumentowali występowanie bazowego mikrobiomu, czyli gromad Firmicutes i Bacteroidetes, jak i obecność różnic osobniczych między badanymi owcami. W tym doświadczeniu bazowa populacja mikrobiologiczna została z kolei wykazana na wyższym poziomie - ponad $70 \%$.

W ostatnim czasie brana jest również pod uwagę $\mathrm{dz}$ iedziczność mikrobiomu. Przeprowadzone w ostatnim czasie badania na myszach, wykazały wpływ genetyki gospodarza na wykształcenie się indywidualnej kompozycji drobnoustrojów jelitowych $u$ tych zwierząt. Natomiast $w$ przypadku przeżuwaczy stwierdzono, że geny ojcowskie (reproduktorów) mogą wpłynąć zarówno na wskaźniki produkcyjne, jak i na mikrobiom potomstwa, w szczególności na poziom archeonów w układzie pokarmowym $[40,48,62,70]$. Doświadczenia nad odziedziczalnością mikrobiomu sugerują jego potencjalną dziedziczność przez pośredni związek $\mathrm{z}$ rasą. Badania przeprowadzone na trzech rasach owiec, utrzymywanych w takich samych warunkach oraz żywione tą samą paszą, wykazały zmnieność w składzie podstawowego mikrobiomu między rasami [71]. Podobne rezultaty uzyskał także w swoich badaniach na bydle i jakach Xin i in. [72]. Autorzy sugerują, że zarówno podłoże geograficzne, jak i genetyczne miały znaczący wpływ na różnice w składzie mikrobiologicznym zwierząt. Podobne wnioski zostały opisane również $\mathrm{w}$ badaniach przeprowadzonych na dwóch rasach owiec przez Douglas $\mathrm{i}$ in. [73].
Ponadto zwierzęta różnią się mikrobiomem żwacza w zależności od płci oraz temperamentu, co może sugerować, że genetyka i fizjologia gospodarza jest skorelowana ze strukturą mikrobiologiczną układu pokarmowego [70,74]. Na mikrobiom mają wpływ czynniki związane z rozrodem tj. ciąża czy ruja, a także różnice $\mathrm{w}$ poziomie niektórych hormonów. Czynniki te często zróżnicowane są ze względu na płeć [70,74-76]. W badaniach przeprowadzonych na myszach w okresie ciąży wykazano, że w przypadku samic dochodzi do zmniejszenia wrażliwości na insulinę, a także zmienia się ich mikrobiom, przygotowując je na gromadzenie zapasów energetycznych na okres odchowu potomstwa. W doświadczeniu wykazano, że doszło do spadku poziomu gromad Firmicutes i Actinobacteria między pierwszym a trzecim trymestrem ciąży, przy równoczesnym wzroście liczebności Bacteroidetes. Jednakże przeprowadzone zaszczepienie mikrobiomu myszy ciężarnych, u myszy niebędących w ciąży, skutkowało wystąpieniem u nich otyłości. Dodatkowo, badania wykonane przez Meon i in. [77] wskazują, że poziom hormonów płciowych może mieć znaczenie w zmienności mikrobiologicznej układu pokarmowego. W badaniu Markle i in. [78] przeprowadzonym na myszach dowodzą bezpośrednią interakcję między hormonami płciowymi a mikroflorą układu pokarmowego. Samce charakteryzowały się ogólnie wyższym poziomem gromady Bacteroidetes i Firmicutes w porównaniu do samic, z kolei samice charakteryzowały się wyższym w porównaniu do samców poziomem gromady Proteobacteria. Wykazano również, że manipulacja mikrobiomem samic poprzez zwiększenie poziomu testosteronu spowodowała zmianę w mikroflorze układu pokarmowego, co skutkowało wzrostem poziomu bakterii z obu gromad w porównaniu do grup kontrolnych. Największy wzrost nastąpił w przypadku gromady Firmicutes (głównie zwiększył się poziom rodzaju Clostridia).

\section{PIŚMIENNICTWO}

1. Roszkowski A (2011) Technologie produkcji zwierzęcej a emisje gazów cieplarnianych. Problemy Inżynierii Rolniczej 19: 83-97

2. Cholewińska P, Czyż K, Nowakowski P, Wyrostek A (2020) The microbiome of the digestive system of ruminants-a review. Animal Health Research Reviews 21(1): 1-12

3. Tanca A, Fraumene C, Manghina V, Palomba A, Abbondio M, Deligios M, Uzzau S (2016) Diversity and functions of the sheep faecal microbiota: a multiomic characterization. Microb Biotech 10(3): 541-554

4. O'Hara E, Neves AL, Song Y, Guan LL (2020) The Role of the Gut Microbiome in Cattle Production and Health: Driver or Passenger?. Annual Review of Animal Biosciences 8: 199-220

5. Wang L, Zhang K, Zhang C, Feng Y, Zhang X, Wang X, Wu G (2019) Dynamics and stabilization of the rumen microbiome in yearling Tibetan sheep. Sci Rep 9(1): 1-9

6. Von Engelhardt W (2010) Fizjologia zwierząt domowych. Tom 2. Wydawnictwo Galaktyka. Łódź.

7. Cholewińska P, Górniak W, Wojnarowski K (2021) Impact of selected environmental factors on microbiome of the digestive tract of ruminants. BMC Vet Res 17(1): 1-10

8. Henderson G, Cox F, Ganesh S, Jonker A, Young W, Abecia L, Attwood GT (2015) Rumen microbial community composition varies with diet and host, but a core microbiome is found across a wide geographical range. Sci Rep 5(1): 1-13

9. Jewell KA, McCormick CA, Odt CL, Weimer PJ, Suen G (2015) Ruminal bacterial community composition in dairy cows is dynamic over the course of two lactations and correlates with feed efficiency. Appl Environ Microbiol 81(14): 4697-4710 
10. Khafipour E, Li S, Tun HM, Derakhshani H, Moossavi S, Plaizier JC (2016) Effects of grain feeding on microbiota in the digestive tract of cattle. Anim Front 6(2): 13-19

11. Khafipour E, Li S, Plaizier JC, Krause DO (2009) Rumen microbiome composition determined using two nutritional models of subacute ruminal acidosis. Appl Environ Microbiol 75(22): 7115-7124

12. Zeng Y, Zeng D, Ni X, Zhu H, Jian P, Zhou Y, Pan K (2017) Microbial community compositions in the gastrointestinal tract of Chinese Mongolian sheep using Illumina MiSeq sequencing revealed high microbial diversity. Amb Express 7(1): 1-10

13. Van Gylswyk NO, Van Der Toorn JJTK (1987) Clostridium aerotolerans sp. nov., a xylanolytic bacterium from corn stover and from the rumina of sheep fed corn stover. Int J System Evol Microbiol 37(2): 102-105

14. Paster BJ, Russell JB, Yang CMJ, Chow JM, Woese CR, Tanner R (1993) Phylogeny of the ammonia-producing ruminal bacteria Peptostreptococcus anaerobius, Clostridium sticklandii, and Clostridium aminophilum sp. nov. Int J System Evol Microbiol 43(1): 107-110

15. Dehority BA (2003) Rumen microbiology. Nottingham University Press, Nottingham

16. Wetzels SU, Eger M, Burmester M, Kreienbrock L, Abdulmawjood A, Pinior B, Mann E (2018) The application of rumen simulation technique (RUSITEC) for studying dynamics of the bacterial community and metabolome in rumen fluid and the effects of a challenge with Clostridium perfringens. PloS One 13(2): e0192256

17. Zhou M, Chung YH, Beauchemin KA, Holtshausen L, Oba M, McAllister TA, Guan LL (2010) Relationship between rumen methanogens and methane production in dairy cows fed diets supplemented with a feed enzyme additive. J Appl Microbiol 111(5): 1148-1158

18. Kassow A, Rahmann G, Blank B, Paulsen HM, Aulrich K (2009) Studies on greenhouse gas emissions in organic and conventional dairy farms, W: Rahmann, Gerold (red) Ressortforschung für den Ökologischen Landbau 2009. Johann Heinrich von Thünen-Institut-Bundesforschungsinstitut für Ländliche Räume, Wald und Fischerei (vTI), str. 65-76

19. Newbold CJ, Wallace RJ, McIntosh FM (1996) Mode of action of the yeast Saccharomyces cerevisiae as a feed additive for ruminants. Brit J Nutr 76(2): 249-261

20. Salminen S., Ouwehand AC, Isolauri E (1998) Clinical applications of probiotic bacteria. Int Dairy J 8(5-6): 563-572

21. Makarova K, Slesarev A, Wolf Y, Sorokin A, Mirkin B, Koonin E, Shakhova V (2006) Comparative genomics of the lactic acid bacteria. Proc Nat Acad Sci 103(42): 15611-15616

22. Gajewska J, Blaszczyk MK (2012) Probiotyczne bakterie fermentacji mlekowej (LAB). Post Mikrobiol 1(51): 55-65

23. Jami E, White BA, Mizrahi I (2014) Potential role of the bovine rumen microbiome in modulating milk composition and feed efficiency. PloS One 9(1): e85423

24. Dodd D, Kiyonari S, Mackie RI, Cann IK (2010) Functional diversity of four glycoside hydrolase family 3 enzymes from the rumen bacterium Prevotella bryantii B14. J Bacteriol192(9): 2335-2345

25. Rolfe RD (2000) The role of probiotic cultures in the control of gastrointestinal health. Journal Nutr 130: 396S-402S

26. Avguštin G, Wright F, Flint HJ (1994) Genetic diversity and phylogenetic relationships among strains of Prevotella (Bacteroides) ruminicola from the rumen. International J System Evol Microbiol 44(2): 246-255

27. Murray PR, Rosenthal KS, Pfaller MA (2016) Medical microbiology. Elsevier Health Sciences.

28. Bentley R, Meganathan R (1982) Biosynthesis of vitamin K (menaquinone) in bacteria. Microbiol Rev 46(3): 241

29. Hudault S, Guignot J, Servin AL (2001) Escherichia coli strains colonising the gastrointestinal tract protect germfree mice against Salmonella typhimurium infection. Gut 49(1): 47-55

30. Laven RA, Ashmore A, Stewart CS (2003) Escherichia coli in the rumen and colon of slaughter cattle, with particular reference to E. coli O157. Vet J 165(1): 78-83
31. Madigan MT, Martinko J (2005) Brock Biology of Microorganisms 11: 149-152

32. Takahashi Y, Omura S (2003) Isolation of new actinomycete strains for the screening of new bioactive compounds. J Gen Appl Microbiol 49(3): 141-154

33. Michelland RJ, Monteils V, Combes S, Cauquil L, Gidenne T, Fortun-Lamothe L (2010) Comparison of the archaeal community in the fermentative compartment and faeces of the cow and the rabbit. Anaerobe 16(4): 396-401

34. Kong Y, Xia Y, Seviour R, Forster R, McAllister TA (2013) Biodiversity and composition of methanogenic populations in the rumen of cows fed alfalfa hay or triticale straw. FEMS Microbiol Ecol 84(2): 302-315

35. Efenberger M, Brzezińska-Błaszczyk E, Wódz K (2014) Archeony drobnoustroje ciągle nieznane. Post Hig Med Dosw 68: 1452-1463.

36. Moss AR, Jouany JP, Newbold J (2000) Methane production by ruminants: its contribution to global warming. Ann Zootech 49(3): 231-253

37. Janssen PH, Kirs M (2008) Structure of the archaeal community of the rumen. Appl Environ Microbiol 74(12): 3619-3625

38. Knecht D, Cholewińska P, Jankowska-Mąkosa A, Czyż K (2020) Development of Swine's Digestive Tract Microbiota and Its Relation to Production Indices - A Review. Animals 10(3): 527

39. Jin D, Kang K, Wang H, Wang Z, Xue B, Wang L, Peng Q (2017) Effects of dietary supplementation of active dried yeast on fecal methanogenic archaea diversity in dairy cows. Anaerobe 44: 78-86

40. Shi W, Moon CD, Leahy SC, Kang D, Froula J, Kittelmann S, Kelly WJ (2014) Methane yield phenotypes linked to differential gene expression in the sheep rumen microbiome. Genome Res 24(9): 1517-1525

41. Gao F, Warren A, Zhang Q, Gong J, Miao M, Sun P, Song W (2016) The all-data-based evolutionary hypothesis of ciliated protists with a revised classification of the phylum Ciliophora (Eukaryota, Alveolata). Sci Rep 6: 24874

42. Radwan P, Skrzydło-Radomańska B (2013) Rola mikroflory jelitowej w zdrowiu i chorobie. Gastroenterologia Praktyczna 2: 1-11

43. Jami E, Israel A, Kotser A, Mizrahi I (2013) Exploring the bovine rumen bacterial community from birth to adulthood. ISME J 7(6): 1069-1079

44. Yáñez-Ruiz DR, Abecia L, Newbold CJ (2015) Manipulating rumen microbiome and fermentation through interventions during early life: a review. Front Microbiol 6: 1133

45. Abecia L, Martín-García AI, Martínez G, Newbold CI, Yáñez-Ruiz DR (2013) Nutritional intervention in early life to manipulate rumen microbial colonization and methane output by kid goats postweaning. J Animal Sci 91(10): 4832-4840

46. Li M, Zhou M, Adamowicz E, Basarab JA (2012) Characterization of bovine ruminal epithelial bacterial communities using $16 \mathrm{~S}$ rRNA sequencing, PCR-DGGE, and qRT-PCR analysis. Vet Microbiol 155(1): $72-80$

47. Tamate H, McGilliard AD, Jacobson NL, Getty R (1962) Effect of various dietaries on the anatomical development of the stomach in the calf. J Dairy Sci 45(3): 408-420

48. Malmuthuge N (2017) Understanding host-microbial interactions in rumen: searching the best opportunity for microbiota manipulation. J Anim Sci Biotech 8(1): 8

49. Fonty G, Gouet P, Jouany JP, Senaud J (1987) Establishment of the microflora and anaerobic fungi in the rumen of lambs. Microbiology 133(7), 1835-1843.

50. Deng L, He C, Zhou Y, Xu L, Xiong H (2017) Ground transport stress affects bacteria in the rumen of beef cattle: A real-time PCR analysis. Anim Sci J 88(5): 790-797

51. Vd'ačný P, Orsi W, Bourland WA, Shimano S, Epstein SS, Foissner W (2011) Morphological and molecular phylogeny of dileptid and tracheliid ciliates: Resolution at the base of the class Litostomatea (Ciliophora, Rhynchostomatia). Eur J Protistol 47(4): 295-313

52. Salcedo J, Frese SA, Mills DA, Barile D (2016) Characterization of porcine milk oligosaccharides during early lactation and their relation to the fecal microbiome. J Dairy Sci 99(10): 7733-7743

53. Bailey MT (2016) Psychological stress, immunity, and the effects on indigenous microflora. Adv Exp Med Biol 874: 191-212 
54. Olszewska J, Jagusztyn-Krynicka EK (2012) Human Microbiome Project-Mikroflora jelit oraz jej wpływ na fizjologię i zdrowie człowieka. Post Mikrobiol 51(4): 243-256

55. Castellazzi A, Tagliacarne SC, Soldi S, Perna S, Ziviani L, Milleri S, Valsecchi C (2018) Stress and immune function: there is a role for the gut microbiota?. J Clin Gastroenterol 52: 66-67

56. De Nardi R, Marchesini G, Li S, Khafipour E, Plaizier KJ, Gianesella M, Segato S (2016) Metagenomic analysis of rumen microbial population in dairy heifers fed a high grain diet supplemented with dicarboxylic acids or polyphenols. BMC Vet Res12(1): 29

57. Kosaka T, Kato S, Shimoyama T, Ishii S, Abe T, Watanabe K (2008) The genome of Pelotomaculum thermopropionicum reveals niche-associated evolution in anaerobic microbiota. Genome Res 18(3): 442-448

58. Hernandez-Sanabria E, Goonewardene LA, Li M, Mujibi DF, Stothard P, Moore SS, Leon-Quintero MC (2010) Correlation of particular bacterial PCR-denaturing gradient gel electrophoresis patterns with bovine ruminal fermentation parameters and feed efficiency traits. Appl Environ Micr 76(19): 6338-6350

59. McCann JC, Wickersham TA, Loor JJ (2014) High-throughput methods redefine the rumen microbiome and its relationship with nutrition and metabolism. Bioinform Biol Insights 8(8): 109-125

60. Mao SY, Huo WJ, Zhu WY (2016) Microbiome-metabolome analysis reveals unhealthy alterations in the composition and metabolism of ruminal microbiota with increasing dietary grain in a goat model. Environ Microbiol 18(2): 525-541

61. Fung T, Olson C, Hsiao E (2017) Interactions between the microbiota, immune and nervous systems in health and disease. Nat Neuroscience 20: $145-55$

62. Meale SJ, Li S, Azevedo P, Derakhshani H, Plaizier JC, Khafipour E, Steele MA (2016) Development of ruminal and fecal microbiomes are affected by weaning but not weaning strategy in dairy calves. Front Microbiol 7: 582

63. Li S, Khafipour E, Krause DO, Rodriguez-Lecompte JC, Plaizier JC (2010) Free endotoxins in the feces of lactating dairy cows. Can J Anim Sci 90(4): 591-594

64. Malmuthuge N, Guan LL (2016) Gut microbiome and omics: a new definition to ruminant production and health. Anim Front 6(2): 8-12

65. Turnbaugh PJ, Hamady M, Yatsunenko T, Cantarel BL, Duncan A, Ley RE, Egholm, M (2009) A core gut microbiome in obese and lean twins. Nature 457(7228): 480-484

66. Qin J, Li R, Raes J, Arumugam M, Burgdorf KS, Manichanh C, Mende DR (2010) A human gut microbial gene catalogue established by metagenomic sequencing. Nature 464(7285): 59-65
67. Lopes LD, de Souza Lima AO, Taketani RG, Darias P, da Silva LRF, Romagnoli EM, Mendes R (2015) Exploring the sheep rumen microbiome for carbohydrate-active enzymes. Antonie Van Leeuwenhoek 108(1): 15-30

68. Li B, Zhang K, Li C, Wang X, Chen Y, Yang Y (2019) Characterization and comparison of microbiota in the gastrointestinal tracts of the goat (capra hircus) during preweaning development. Front Microbiol 10: 2125

69. Mamun MAA, Sandeman M, Rayment P, Brook-Carter P, Scholes E, Kasinadhuni N, Greenhill AR (2019) The composition and stability of the faecal microbiota of Merino sheep. J Appl Microbiol 128(1): 280-291

70. Sasson G, Ben-Shabat SK, Seroussi E, Doron-Faigenboim A, Shterzer N, Yaacoby S, Mizrahi I (2017) Heritable bovine rumen bacteria are phylogenetically related and correlated with the cow's capacity to harvest energy from its feed. MBio 8(4): e00703-17

71. Cholewińska P, Wołoszyńska M, Michalak M, Czyż K, Rant W, Janczak M (2020) Evaluation of Changes in the Levels of Firmicutes and Bacteroidetes Phyla of Sheep Feces Depending on the Breed. Animals 10(10): 1901

72. Xin J, Chai Z, Zhang C, Zhang Q, Zhu Y, Cao H, Ji Q (2019) Comparing the microbial community in four stomach of dairy cattle, yellow cattle and three yak herds in Qinghai-Tibetan Plateau. Front Microbiol 10: 1547

73. Douglas JL, Worgan HJ, Easton GL, Poret L, Wolf BT, Edwards A, McEwan NR (2015) Microbial diversity in the digestive tract of two different breeds of sheep. J Appl Microbiol 120(5): 1382-1389

74. Gart EV, Lawhon SD, Suchodolski JS, Randel RD, Welsh TH (2019) The relationship of weaning stress, sex and temperament on fecal microbiota and metabolites in Brahman calves. J Anim Sci 97: 47-47

75. Jašarević E, Howard CD, Misic AM, Beiting DP, Bale TL (2017) Stress during pregnancy alters temporal and spatial dynamics of the maternal and offspring microbiome in a sex-specific manner. Sci Rep 7: 44182

76. Hallmaier-Wacker LK, Lueert S, Roos C, Knauf S (2019) The influence of sex on the urogenital microbiome of rhesus monkeys. bioRxiv

77. Menon R, Watson SE, Thomas LN, Allred CD, Dabney A, Azcarate-Peril MA, Sturino JM (2013) Diet complexity and estrogen receptor $\beta$ status affect the composition of the murine intestinal microbiota. Appl Environ Microbiol 79(18): 5763-5773

78. Markle JG, Frank DN, Mortin-Toth S, Robertson CE, Feazel LM, Rolle-Kampczyk U, Danska JS (2013) Sex differences in the gut microbiome drive hormone-dependent regulation of autoimmunity. Science 339(6123): 1084-1088

\section{Selected factors affecting the ruminant gastrointestinal microbiome and its basal composition}

\section{Paulina Cholewińska ${ }^{\varpi}$, Natalia Szeligowska, Jakub Smoliński, Marcel Bawej}

Institute of Animal Breeding, Wrocław University of Environmental and Life Sciences, Wrocław, Poland

${ }^{\square}$ Corresponding author: paulina.cholewinska@upwr.edu.pl

Key words: microbiome, ruminants, digestive tract, diet, biological factors, genetic factors

\section{ABSTRACT}

The microbiome of the ruminant digestive system is one of the most complex examples of the interaction between microorganisms and the host. The microbiome of the digestive system of ruminants is necessary to obtain energy from plant food, which would not be possible without its participation. The microbiome of the digestive system consists of bacteria, archaea, protozoa and fungi. Bacteria are the most numerous group, with Firmicutes and Bacteroidetes being the main clusters. The composition of the microbiome, both quantitatively and qualitatively, depends on factors such as diet, age, health, and the environment. Additionally, it may be influenced by genetic or biological factors (e.g. gender). Microorganisms living in the digestive system of ruminants significantly affect their health or production indicators, which in turn is associated not only with the proper absorption of nutrients from food, but also with the function of the microbiome as a specific immune system. 